\title{
Prevalence Of Bacterial Vaginosis Among Female Students Of Michael Okpara University Of Agriculture,Umudike, Abia State, Nigeria
}

\author{
Udenze Chikwendu Lawrence ${ }^{1}$, Achi O.K ${ }^{2}$, Obeagu Emmanuel Ifeanyi ${ }^{3}$ and \\ Elemchukwu Queen ${ }^{4}$ \\ 1.Medical Doctor, University Health Services Department,Michael Okpara University of \\ Agriculture,Umudike, Nigeria. \\ 2.Professor,Department of Microbiology, Michael Okpara University of Agriculture,Umudike, Nigeria. \\ 3.Diagnostic Laboratory Unit, University Health Services Department,Michael Okpara University of \\ Agriculture,Umudike, Nigeria. \\ 4.River State College of Health Science and Technology,Port Harcourt,River State,Nigeria.
}

\begin{abstract}
The prevalence of bacterial vaginosis in both self reported symptomatic and asymptomatic female students of the Michael Okpara University of Agriculture,Umudike, was investigated. Two hundred high vaginal swabs were collected, cultured and their susceptibility to various antibiotics was determined. Out of 200 samples examined,148(74\%) had one form of microbial organism or the other, ranging from bacteria to fungi; bacteria making up to 104 of the isolates while 44 isolates were of fungal infection. Fifty two (52) patients representing $26 \%$ had none. The frequency of isolation of organism was E.coli $68(46.0 \%)$, Yeast, $44(29.7 \%)$ and Staphylococcus aureus 36(24.3\%).Almost all the patients who practiced douching with soap and antiseptics had more than $90 \%$ of the symptoms of vaginal itching, dour and discharge. This shows that there is significant effect of douching method on the various indications for BV. The low sensitivity(28.1\%), low positive predictive value and high specificity(65\%), using vaginal discharge as a gold standard, pointed more to bacterial vaginosis.The most effective antibiotic against E.coli isolates was ciprofloxacin,52(76.5\%) and tarvid,(77.9\%), while tetracycline $2(3.0 \%)$ was the least effective. Staphylococcus aureus isolate was most sensitive to ciprofloxacin 33(91.7\%) whereas they were resistant to cotrimoxazole and nalidixic acid, $0(0 \%)$ each. This study emphasizes the need for routine HVS examination among the female students, the need to stop the practice of douching especially with antiseptics and also on the importance of restriction of indiscriminate use and abuse of antibiotics to forestall resistance.
\end{abstract}

Keywords: Prevalence, Bacteria Vaginosis and Fungi and Sensitivity.

\section{Introduction}

Bacterial vaginosis (BV) is the most common cause of vaginal discharge among women in reproductive age with a prevalence of 9-37\%, depending on the population studied (Goldberg et al., 1996). The prevalence of vaginal infections, particularly BV, is high in many countries in Sub-Saharan Africa. For example, $20 \%$ to $50 \%$ of women of reproductive age are affected in Zimbabwe (van De Wijgert et al., 2000). It is characterized by a disorder of the vaginal ecosystem characterized by a change in the vaginal flora from the normally predominant lactobacillus to one dominated by sialidase enzyme- producing organisms.

The vagina is a complicated environment containing a number of microbial species in variable quantities and relative proportions (Mumtaz, et al., 2008). A complex and intricate balance of microorganisms maintains the normal vaginal flora and changes with a multitude of events in the patient's life (Cook, et al., 2001). The dominant microbial species is Lactobacillus, which maintains the generally acidic vaginal $\mathrm{pH}$ (Khan and Khan, 2004).

The presence in the vagina of other bacteria such as Gardnerella vaginalis, group B streptococci and Esherichia coli termed commensal bacteria (Laren and Monif, 2001) is not synonymous with infection (Cook, et al., 2001). According to Hammill (1989), the incidence of E. coli in the vagina of normal, pre-menopausal, nonpregnant, asymptomatic women is about $21 \%$. However, vaginal E. coli may also cause symptomatic infections such as vaginitis or tubo-ovarian abscess and is associated with life-threatening neonatal sepsis (Percival-Smith, 1983).

According to Larsen and Monif (2001), G. vaginalis was isolated from the vaginal samples obtained from 150 of 446 women who visited a student health center and who were free of clinically overt disease. During the past several decades, the many published survey of vaginal flora specimens obtained from asymptomatic women have clearly shown that Candida albicans may be present without the typical symptoms of yeast vaginitis (Glover and Larsen, 1998). Bacteria that are normal constituents of the vaginal flora of the host 
have the potential to cause symptoms of disease, but they apparently require some alteration in the microenvironment to do so (Larsen and Monif, 2001).

Other microorganisms such as Neisseria gonorrhoeae, Streptococcus pyogenes, Streptococcus pneumonia, Haemophilus influenza, listeria monocytogenes and Trichomonas vaginalis are not ordinarily part of the flora of the female genital tract, but they bring the potential for disease to the vaginal/endocervical area by virtue of their inherent biological properties, (Larsen and Monif, 2001). Although the presence of these properties do not guarantee that disease will occur.

The frequent cause of vaginal discharge is an infection or colonization with different microorganisms (Mylonas and Friese, 2007). Vaginitis, whether infectious or not, poses one of the most common problems that lead women to seek out an obstetrician or gynecologist (Adad et al., 2001; Mumtaz et al., 2008), in approximately 10 million office visit annually (Kent, 1991; Donder et al., 2002). The tradition of diagnosis of vaginitis which involves patient's symptoms, clinical findings observed during vaginal examination, and laboratory analysis of vaginal fluid and treatment can be elusive, leading to lack of relief from the symptoms (Schaaf, et al., 1990; Bornstein et al., 2001).

Although some pathologic conditions causing vaginitis are well defined like bacterial vaginosis, vulvovaginal candidiasis, and trichomoniasis yet, $7-72 \%$ of women with vaginitis may remain undiagnosed and such forms of abnormal vaginal flora neither considered as normal, nor can be called bacterial vaginosis have been termed as 'intermediate flora' and its management probably differ from that of bacterial vaginosis (Vigneswaran and McDonald, 1994; Mumtaz et al., 2008).

Data on asymptomatic lower genital tract infections among females are sparse. In a prospective study of genital tract infections in a family planning clinic (among the women with both signs and symptoms), Trichomonas vaginalis, Candida albicans and bacterial vaginosis were equally prevalent (Riordan et al., 1980). Also Neisseria gonorrhoeae was isolated from $4 \%$ of women with, and $1 \%$ of those without symptoms. Klufio et al., (1995) reported the presence of Candida in 48 women, Trichomonas vaginalis in 39 and bacterial vaginosis in 48 in the study of prevalence of vaginal infections (with bacterial vaginosis, Trichomonas vaginalis and candida albicans) among pregnant women at the Port Moresby General Hospital Antenatal clinic.

In a study of bacterial vaginosis and lower genital tract infections in women attending out-patient clinic at a tertiary institution serving a developing community, Kharsany et al., (1999) detected vaginal infections in a total of 104 women out of 208 examined, endocervical infections alone in 18 and concurrent vaginoendocervical infection in 41 , bacterial vaginosis was diagnosed in 73 women. Trichomonas vaginalis was detected significantly more often in women attending the sexually transmitted disease (STD) and antenatal clinics. Also Microorganisms such as Gardnerella vaginalis, Mycoplasma hominis, anaerobes and curved Gram negative rods were found in significant higher number of women with bacterial vaginosis. In a study to investigate the possible role of microorganisms in vulvovaginitis among 50 virgin girls; Mahdi and Maysoon (2001) reported Staphylococcus aureus (10\%) Enterococcus faecalis $(10 \%)$ and Esherichia coli $(8 \%)$ as the most common pathogens. Eggs of E. vermicularis and trophozoites of T. vaginalis were recovered at a rate of $4 \%$ and $6 \%$ respectively. However, Candida was diagnosed at a rate of $8 \%$. Non specific vulvovaginitis was exceedingly common (28\%). Akerele et al., (2002) investigated the prevalence of asymptomatic genital infection among pregnant women in Benin City, Nigeria. They reported a significant microbial growth in 300 samples, giving a prevalence rate of $60 \%$ for asymptomatic genital infection. Candida albicans (65\%), Staphylococcus aureus (51.8\%) and enterobacteriacae (E. coli, Klebsiella species) were predominanalty isolated, followed by Trichomonas vaginalis and Neisseria gonorrhoea. Most of the isolated bacteria were susceptible to ciprofloxacin ceftazidime, cotrimoxazole, norfloxacin and augumentin. All the isolates, except Streptococcus faecalis were resistant to ampicillin. In a related study by Anh et al., (2003) to determine the prevalence of lower genital tract infection (LGTI) with Candida sp. among 1000 symptomatic and asymptomatic women attending maternal and child health family planning clinic in Hanoi, Vietnam, the overall prevalence of Candida sp. was $11.1 \%$, T. vaginalis (13.1\%), non gonococcal infection was found; the prevalence of Chlamydia trachomatis was $4.4 \%$ and of bacterial vaginosis $(3.5 \%)$. They reported that prevalence of these infections was quite similar, both in the asymptomatic and the symptomatic group.

\section{AIMS AND OBJECTIVES}

This study therefore was aimed at:

- determining the prevalence of BV among women self-presenting with vaginal discharge at Michael Okpara University Umudike attending the institution's Medical Centre,

- investigating the microorganisms responsible for the prevalence of symptomatic and asymptomatic bacterial vaginosis,

- determining the antibiotic susceptibility pattern of the isolates to commonly used antimicrobial agents. 


\section{STUDY POPULATION}

\section{Materials And Methods}

The study was comprised of 200 female students of the Michael Okpara University of Agriculture, Umudike, Abia State aged between 17-29 years old. All potential eligible patients were interviewed and informed consent was obtained. Demographic data regarding their age, genital tract infections, douching history and methods used and usage of antibiotics were collected. Clinical data relating to vaginal discharge, vaginal odour and vaginal itching or their absence were collected. The female students were excluded if they were placed on antibiotics or are already undergoing treatment with any symptomatic pelvic inflammatory disease (PID) or any other genital tract infection for at least 2 weeks prior to the study. Ethical committee of the University's Medical Centre gave approval for the work to be done in the Centre.

\section{SAMPLE COLLECTION}

A sterile swab stick was used to collect the vaginal swabs. Self-collected vaginal samples were obtained twice weekly. Participants were instructed to insert the vaginal swab 1-2 inches into the vagina, twist the swab to collect material on all sides of the cotton tip, wipe in several full circles on the vaginal wall, keep in the vagina for $20 \mathrm{sec}$, and then roll each swab across a slide and allow the material to air-dry. Each sample was labeled with a serial number and kept at a temperature of $4^{0} \mathrm{C}$ for onward transmission to the laboratory not more than $2 \mathrm{~h}$ after collection for analysis. Samples were collected between March to July 2010.

\section{MICROBIOLOGICAL ANALYSIS}

Swabs were rinsed in $9 \mathrm{ml}$ of a quarter Ringer's solution in a test tube to make a dilution of $10^{-1}$.

Serial dilution was carried out by transferring one $\mathrm{ml}$ from $10^{-1}$ dilution into a fresh tube of $9 \mathrm{ml}$ of Ringer's solution to make $10^{-2}$ dilution. The samples were inoculated on blood, MacConkey's agar and chocolate agar according to standard protocol as described by Cheesbrough (2000) after which the Petri dishes were incubated at $37^{\circ} \mathrm{C}$ for $24 \mathrm{~h}$, while the Chocolate agar media were anaerobically incubated. Duplicate plates of plate count agar (PCA) were inoculated from each dilution and incubated aerobically at $37^{\circ} \mathrm{C}$ for $24 \mathrm{~h}$. Colony counts yielding bacterial growth of $10^{5} \mathrm{cfu} / \mathrm{ml}$ or more of pure isolates per $\mathrm{ml}$ were recorded as showing significant growth.

Morphologically different colonies from the plate count were subcultured repeatedly into nutrient agar slants by streaking and incubated at $37^{\circ} \mathrm{C}$ for $24-48 \mathrm{~h}$.

\section{BIOCHEMICAL CHARACTERIZATION AND IDENTIFICATION OF BACTERIAL ISOLATES}

The bacterial colonies were examined for appearance based on shape, elevation, edge and pigmentation. The bacterial isolates were characterized according to the methods described by Cheesbrough (2000) in which the colonial characteristics on Plate Count Agar (PCA) and MacConkey agar, Gram reaction and biochemical tests such as catalase, coagulase, indole, citrate utilization, urease activity, oxidase, methyl red, Voges-Proskauer and motility were conducted.

\section{Gram Reaction}

The Gram reaction was used to classify the isolates into gram positive and gram negative bacteria after examining the agar plates. A thin smear of young bacterial culture (18-24hours old) was made on a clean grease free glass slide, it was allowed to air dry, then heat fixed by passing it through a Bunsen burner flames about 3 times. The heat-fixed smear was then covered with crystal violet stain for 30-60seconds. The stain was quickly washed off with clean water. The water was tipped off and the smear was covered with Lugol's iodine for 3060 seconds. The iodine was washed with clean water. The smear was decolourized rapidly for about 20 seconds with $95 \%$ ethanol. The smear was quickly washed with clean water and then covered with dilute carbol fuschin for 30 seconds. The stain was washed off with clean water and the slide was allowed to dry at room temperature. The gram stained slide was examined first with $\mathrm{x} 40$ objective lens to check for the staining and distribution of the gram stained bacteria, then with oil immersion objective lens(x100) to look for the bacteria. Gram positive bacteria appeared purple while gram negative appeared red or pink.

\section{Motility Test}

This test was used to detect motile bacteria using the 'hanging drop' method. A little petroleum jelly was placed round at the centre of a clean grease free cover slip. Then a drop of normal saline was placed in the ring. The bacteria culture was emulsified on the saline placed at the centre of the cover slip. Then, the slide was carefully placed on the cover-slip and quickly inverted (with the cover-slip sticking at the glass slide by means of the petroleum jelly). The slide was viewed using $\mathrm{x} 40$ objective lens at reduced illumination for maximum contrast. A directional movement of the organism is a positive test. 


\section{Catalase Test}

A sterile wooden spatula containing a good growth of the organism was dipped into 2-3ml hydrogen peroxide contained in a test tube. The pressure of gas bubbles indicates a positive reaction (catalase produced). No release of bubbles showed negative reaction (no catalase produced).

\section{Coagulase Test}

The slide method described by Cheesbrough (2000) was used for the test. A drop of normal saline was placed on each end of a slide. An 18-24 hours old culture of test organism was emulsified in each of the drops to make two thick suspensions. Thereafter, a drop of human plasma was added to one of the suspensions. The mixture was stirred for about $5 \mathrm{sec}$. Clumping of the organism within $10 \mathrm{sec}$. is a positive test. No plasma was added to the second suspension which is the control to differentiate any granular appearance of the organism from true coagulase clumping.

\subsubsection{Urease Test:}

The nutrient agar incorporated with urea and phenol red indicator was inoculated with the suspected colony. The culture was incubated at $37^{0} \mathrm{C}$ for $24 \mathrm{~h}$. A positive urease test was shown by a change in colour of the agar from pale yellow to red.

\section{Oxidase Test}

Two drops of freshly prepared oxidase reagent ( $1 \%$ aqueous solution of tetramethyl-pphenylenediamine dihydrochloride) were made on a clean filter paper in a Petri dish. Then, a sterile wooden stick was used to collect the test organism and smeared on the potion of filter paper damped with oxidase reagent. The appearance of blue-purple colour within 10seconds indicates a positive reaction.

\section{Indole Test}

An aliquot of $1.5 \%$ sterile peptone water in a test tube was inoculated with the test bacterium culture and incubated for 48 hours at $30^{\circ} \mathrm{C}$. kovac's reagent, $0.5 \mathrm{ml}$, was added. A red colour indicated positive indole test.

\section{Citrate Utilization}

Simmon's citrate agar was prepared based on manufacturer's instruction, sterilized, poured and allowed to solidify at an angle of $45^{\circ} \mathrm{C}$. The test organism was streaked on the surface of the agar slant and then incubated for about 5 days at $37^{\circ} \mathrm{C}$. A change in the colour of agar medium from green to blue following growth of the organism on the slant indicated a positive test, while the absence of growth and colour change indicated a negative test.

\section{Methyl Red Test}

Two (2) $\mathrm{ml}$ of sterile glucose phosphate peptone water was inoculated with the bacterial isolates and incubated at $37^{\circ} \mathrm{C}$ for 48 hours. 3-5drops of methyl red indicator was added, mixed and read immediately, a bright red colour indicated a positive test indicating acidity, while yellow colour indicated a negative test.

\section{Voges-Proskauer Test}

Two (2) $\mathrm{ml}$ of sterile glucose phosphate peptone water was inoculated with the bacteria culture and incubated at $37^{\circ} \mathrm{C}$ for $48 \mathrm{~h}$. Then, $1 \mathrm{ml}$ of $40 \%$ potassium hydroxide was added followed by $3 \mathrm{ml}$ of $5 \%$ alcoholic alpha-naphthol. The test tube was mixed very well and observed for colour change. A pink-red colour within 2-5 minutes shows a positive test.

\section{Sugar Fermentation Tests}

A $5 \mathrm{ml}$ of $1.5 \%$ peptone water was added with $5 \mathrm{ml}$ of $0.2 \%$ phenol red indicator and sterilized by autoclaving at $121^{\circ} \mathrm{C}$ for 15 minutes. Thereafter, $0.1 \mathrm{ml}$ of $10 \%$ of sterile sugar to be tested was added to the medium aseptically; the sugar was sterilized separately by filtration. The test organism was inoculated into the growth medium and a sterile inverted Durham tubes introduced into each test tube and incubated for $24 \mathrm{~h}$ at $37^{\circ} \mathrm{C}$. The tubes were observed for acid and gas production. Acid production gave a red to yellow colour change, while gas production was identified by air displacement in the inverted Durham tubes.

\section{Antibiotic Susceptibility Testing}

Antibiotic susceptibility was determined by the agar diffusion technique as described by Baker and Breach (1980) and antibiotic discs (Abtek Biologicals Ltd). A sterile cotton swab dipped into the broth culture of isolate was streaked evenly all over the surface of Mueller Hinton Agar and antibiotic disk was placed aseptically on the inoculated plates using sterile forceps. The plates were then incubated for 24 hours at $37^{\circ} \mathrm{C}$. Isolates were considered as sensitive or resistant to an antibiotic according to the diameter of inhibition zone interpretative chart (Clinical Laboratory Standards Institute 2006).

\section{Determination of Minimum Inhibitory Concentrations (MIC)}

Ampicillin was used as the commonly used antibiotic against E. coli for the determination of MIC. This was done using the paper disc method (Oloke, 2000). Sterile paper discs were dipped into different concentrations of antibiotics prepared. Sterile paper disc was dipped into water as control. The soaked discs were each layered on Mueller Hinton Agar plates already seeded with an $18 \mathrm{~h}$. broth culture of the isolate in 
duplicate. Each plate was incubated at $37^{\circ} \mathrm{C}$ for $24 \mathrm{~h}$. This was examined for zones of inhibition. The lowest concentration of antibiotic which inhibited growth was taken as the MIC.

$\begin{array}{lc}\text { Abtek Laboratories UK has the following Antibiotic Discs below: } \\ \text { Ampicillin }(10 \mu \mathrm{g}) & \text { Ampicillin }(25 \mu \mathrm{g}) \\ \text { Chloramphenicol }(10 \mu \mathrm{g}) & \text { Gentamycin }(25 \mu \mathrm{g}) \\ \text { Cloxacillin }(5 \mu \mathrm{g}) & \text { Tetracycline }(25 \mu \mathrm{g}) \\ \text { Erythromycin }(5 \mu \mathrm{g}) & \text { Colistin }(25 \mu \mathrm{g}) \\ \text { Gentamycin }(10 \mu \mathrm{g}) & \text { Streptomycin }(25 \mu \mathrm{g}) \\ \text { Penicillin }(1 \mathrm{iu}) & \text { Nalidixic acid }(25 \mu \mathrm{g}) \\ \text { Streptomycin }(10 \mu \mathrm{g}) & \text { Nitrofurantoin }(200 \mu \mathrm{g}) \\ \text { Tetracycline }(10 \mu \mathrm{g}) & \text { Cotrimoxazole }(25 \mu \mathrm{g})\end{array}$

\section{Results}

Two hundred female undergraduates of Michael Okpara University of Agriculture, Umudike who attended the University's medical centre were examined for bacterial vaginosis. Patients were predominantly aged 17 to 29 years of age. Samples were collected based on three age group brackets of 17-20, 21-24 and 25-29 years with a mean age of 23 years. The results of demographic data stratified by the douching methods, and number of sexual partners were compared with the different age groups as shown in Table 1.

A total of 97 out of the 200 student patients douched with soap, 28 with antiseptics while 75 douched with ordinary water. Out of 69 patients examined within the age group 17-20, 46 had one (1) sex partner, 8 with 2 sex partners while 15 had no partners.

The clinical indications for bacterial vaginosis as observed in this study are shown in Table 2. A large number of the students (71: (35.5\%) out of the 200 presented with one form of symptom or the other. Twenty three (23) presented with vaginal odour, (20) had vaginal discharge, and 28 with itching. Of this numbers, 44(65.2\%) douched with soap, $22(30.4 \%)$ with antiseptics and $5(3 \%)$ douched with water. This result indicates that there was a significant effect $(\mathrm{P} \geq 0.5)$ of douching on the various indications for bacterial vaginosis with higher values recorded for douching with antiseptics.

Table 3 also show the sensitivity, specificity, positive predictive value (PPV) and negative predictive value (NPP) of symptoms associated with BV using vaginal discharge as the gold standard. The sensitivity was calculated as $28.2 \%$, specificity as $65.0 \%$, PPV as $22.0 \%$ and NPP as $72.0 \%$.

The result of the microscopic examination of the samples of the vaginal swabs is reported in Table 4.The results revealed that $98(49.0 \%)$ samples contained significant epithelial cells, $102(51.0 \%)$ contained pus cells, while $24(12.0 \%)$ samples showed the presence of yeast cells. Fewer numbers of samples from the patients showed scanty epithelial cells.

The distribution of microbial load from the samples is indicated in Table 5. A total of 50 samples had significant bacterial growth $\left(\geq 10^{5} \mathrm{cfu} / \mathrm{ml}\right)$ while 54 samples had scanty growth $\left(<10^{5} \mathrm{cfu} / \mathrm{ml}\right)$.

Table 6 show the morphological and biochemical characteristics of the bacterial isolates from vaginal swab cultures of samples after growth on chocolate, MacConkey, Blood, and Nutrient agar. Staphylococcus aureus had a convex, smooth and light yellow colony with entire edge on Nutrient agar plates and appeared as gram positive cocci in clusters. Staphylococcus aureus was negative in urease, motility, oxidase, indole, citrate,VogesProskauer and methyl red tests while it was positive in the catalase and coagulase tests, including the various sugar fermenting tests with glucose, sucrose, lactose, maltose, and mannitol. Escherichia coli on the other hand, had convex, smooth and dark red colony with entire edge on MacConkey agar plates. They appeared as Gram negative straight rods on stained preparations. Biochemical tests showed that Escherichia coli was negative in catalase, coagulase, urease, oxidase and Voges Proskauer tests while in motility, indole and methyl red tests were positive. Sugar fermentation showed it was positive to glucose, lactose and mannitol but was unable to ferment sucrose and maltose.

Yeast isolates from the samples in Table 7 had colonial morphology of moderate, convex or oval creamy colony with entire edge. Gram reaction and cellular characteristics on Sabouraud agar shows budded gram positive cocci in stained preparations.

Table 6 shows the frequency of occurrence of the bacterial isolates from vaginal swab samples. A total of $68(65.4 \%)$ of E. coli was isolated out of a total of 148 isolates. Staphylococcus aureus occurred in a total of $36(34.6 \%$ ), while yeast cells were isolated from 44 of the vaginal swab samples representing $29.7 \%$ of the total organisms isolated.

Table 7 shows the relationship between the different douching methods and the number of microbial counts recorded per method. Out of the 200 samples examined, 97 (48.5\%) douched with soap, 28 (14.0\%) douched with antiseptics while $75(37.5 \%)$ with water. The microbial count of samples from those that douched with soap ranged from $10^{5}-10^{7} \mathrm{cfu} / \mathrm{ml}$. Those that douched with antiseptics were $24(85.7 \%)$. Those who 
douched with water had 50 (66.7\%) microbial counts isolated (table 7). This result shows that douching by the patients had a significant effect $(\mathrm{p} \geq 0.05)$ on the number of microbial counts.

The antibiotic sensitivity pattern of the bacterial isolates as shown in table 8 revealed ciprofloxacin 52 (76.5\%) and tarivid $53(77.9 \%)$ were the most effective antibiotics for E. coli isolates, followed by gentamycin $49(72.1 \%)$. Tetracycline was the least effective antibiotics for E. coli with resistance rate as high as $97.1 \%$ and a sensitivity of $3 \%$,followed by penicillins with resistance rate of $89.7 \%$. Staphylococcus aureus isolated were most sensitive to ciprofloxacin $33(91.7 \%)$ followed by tarivid $34(88.9 \%)$ whereas it was resistant to cotrimoxazole and nalidixic acid with sensitivity of $0(0 \%)$ for each. All the S. aureus isolates showed $100 \%$ resistance to nalidixic acid and cotrimoxazole.

Table 1: Demographic Data Stratified by Douching Methods and Number of Sex Partners

\begin{tabular}{|c|c|c|c|c|c|c|c|}
\hline $\begin{array}{r}\text { Age } \\
\text { range }\end{array}$ & $\begin{array}{l}\text { No of vaginal swabs } \\
\text { examined }\end{array}$ & $\begin{array}{c}\text { No } \\
\text { partners }\end{array}$ & of & $\operatorname{sex}$ & $\begin{array}{l}\text { Douching } \\
\text { with } \\
\text { antiseptic } \\
\text { soap (\%) }\end{array}$ & $\begin{array}{l}\text { Douching } \\
\text { with antiseptics (\%) }\end{array}$ & $\begin{array}{l}\text { Douching with } \\
\text { water }(\%)\end{array}$ \\
\hline $17-20$ & 69 & 15 & 46 & 8 & $31(44.9)$ & $9(13.0)$ & $29(42.0)$ \\
\hline $21-24$ & 78 & 10 & 59 & 9 & $37(47.4)$ & $11(14.1)$ & $30(38.5)$ \\
\hline $25-29$ & 53 & 9 & 39 & 5 & $29(54.7)$ & $8(15.1)$ & $16(30.2)$ \\
\hline
\end{tabular}

Table 2: Indications for Bacterial Vaginosis

\begin{tabular}{lllll}
\hline Indications & $\begin{array}{l}\text { Total No. of patients } \\
\text { with symptoms }\end{array}$ & $\begin{array}{l}\text { Douching with soap } \\
(\%)\end{array}$ & $\begin{array}{l}\text { Douchingwith } \\
\text { antiseptics (\%) }\end{array}$ & $\begin{array}{l}\text { Douching } \\
\text { water (\%) }\end{array}$ \\
\hline Odour & 23 & $15(65.2)$ & $7(30.4)$ & $1(4.3)$ \\
Itching & 28 & $17(60.8)$ & $9(32.1)$ & $2(7.1)$ \\
Yellowish Discharge & 20 & $12(60.0)$ & $6(30.0)$ & $2(10)$ \\
No symptoms & & 53 & 6 & 70 \\
\hline
\end{tabular}

Table 3:Sensitivity, Specificity, Positive Predictive Value and Negative Predictive Value of Symptoms Associated with Bacterial Vaginosis

\begin{tabular}{|c|c|c|c|c|c|c|c|c|}
\hline \multirow[t]{2}{*}{ Test } & \multicolumn{8}{|c|}{$\begin{array}{l}\text { No. of participants with the } \\
\text { following results }(N=200)\end{array}$} \\
\hline & TP & FP & TN & FN & $\begin{array}{l}\text { Sensitivity } \\
(\%)\end{array}$ & $\begin{array}{l}\text { Specificity } \\
(\%)\end{array}$ & PPV (\%) & $\begin{array}{l}\text { NPV } \\
(\%)\end{array}$ \\
\hline Vaginal discharge & 20 & 71 & 129 & 51 & 28.2 & 65.0 & 22.0 & 72.0 \\
\hline
\end{tabular}

Key:

$\mathrm{TP}=$ True Positive

$\mathrm{FP}=$ False Positive

$\mathrm{TN}=$ True Negative

FN $=$ False Negative

$\mathrm{PPV}=$ Positive Predictive Value

NPV $=$ Negative Predictive Value

Table 4: Microscopic Examination of High vaginal swab samples (HVS)

\begin{tabular}{llll}
\hline & Significant Sample & Scanty Sample & No Sample \\
\hline Epithelial Cells (\%) & $98(49.0)$ & $56(28.0)$ & $46(23.0)$ \\
Pus Cells (\%) & $102(51.0)$ & $53(26.5)$ & $45(22.5)$ \\
Yeasts (\%) & $24(12.0)$ & $20(10.0)$ & $156(78.0)$ \\
\hline
\end{tabular}

Key:

Significant sample $=\geq 5 \mathrm{Hpf}$ (High power field)

Scanty sample $=\leq 5 \mathrm{Hpf}$

Table 5:Distribution of Microorganisms isolated from HVS Samples

\begin{tabular}{|c|c|c|c|c|}
\hline Age group & $\begin{array}{l}\text { No. of vaginal swabs } \\
\text { examined }\end{array}$ & $\begin{array}{l}\text { No. of samples with } \\
\text { significant } \\
\text { bacterial growth }\end{array}$ & $\begin{array}{lr}\begin{array}{l}\text { No. of } \\
\text { with }\end{array} & \text { samples } \\
\text { growth } & \text { scanty } \\
\end{array}$ & $\begin{array}{l}\text { No. of samples with } \\
\text { yeast growth }(\%)\end{array}$ \\
\hline $17-20$ & 69 & 17 & 14 & $14(31.8)$ \\
\hline 21-24 & 78 & 23 & 26 & $17(38.6)$ \\
\hline $25-30$ & 53 & 10 & 14 & $13(29.6)$ \\
\hline TOTAL & 200 & 50 & 54 & 44 \\
\hline
\end{tabular}

Note:

Significant growth $=\geq 10^{5}(\mathrm{cfu} / \mathrm{ml})$ 
Scanty growth $=<10^{5}(\mathrm{cfu} / \mathrm{ml})$

Table 6: Occurrence of Microorganisms isolated from Vaginal Swab Samples

\begin{tabular}{lcc}
\hline Organism & Frequency $(\%)$ & $\begin{array}{l}\text { Total swab } \\
\text { samples }\end{array}$ \\
\hline E. coli & $68(46.0)$ & 200 \\
S. aureus & $36(24.3)$ & 200 \\
C. albicans & $44(29.7)$ & 200 \\
Total & $148(100)$ & \\
\hline
\end{tabular}

Table 7: Effect of Douching on the Microbial Count of Vaginal Swabs

\begin{tabular}{|c|c|c|}
\hline Douching & No. of Patients & $\begin{array}{l}\text { No. of Microbial count Isolated } \\
(\%)\end{array}$ \\
\hline Douching with soap & 97 & $74(76.3)$ \\
\hline Douching with antiseptics & 28 & $24(85.7)$ \\
\hline Douching with water & 75 & $50(66.7)$ \\
\hline TOTAL & 200 & 148 \\
\hline
\end{tabular}

Table 8: Antibiotic sensitivity pattern of bacterial isolates

Antibiotics

$\begin{array}{lccc} & \text { Sensitive } & \text { Intermediate } & \text { Resistant. } \\ \text { Gentamycin } & 49(72.1) & 5(7.4) & 14(20.9) \\ \text { Colistin } & 12(18.2) & 11(16.2) & 45(66.2) \\ \text { Nalidixic acid } & 14(21.1) & 6(8.8) & 48(70.6) \\ \text { Nitrofurantoin } & 16(24.2) & 8(11.8) & 44(64.7) \\ \text { Cotrimoxazole } & 20(30.3) & 1(1.5) & 47(69.1) \\ \text { Streptomycin } & 6(9.1) & 2(2.9) & 60(88.2) \\ \text { Tetracycline } & 2(3.0) & 0(0) & 66(97.1) \\ \text { Ampicillin } & 3(4.5) & 8(11.8) & 57(83.8) \\ \text { Chloramphenicol } & 5(7.4) & 11(16.2) & 52(76.5) \\ \text { Ciprofloxacin } & 52(76.5) & 12(17.7) & 4(5.9) \\ \text { Tarivid } & 53(77.9) & 12(17.7) & 3(4.4) \\ \text { Augument } & 10(14.7) & 19(27.9) & 39(57.4) \\ \text { Penicillins } & 4(5.8) & 3(4.4) & 61(89.7) \\ \text { Erythromycin } & 8(11.8) & 4(5.9) & 56(82.4)\end{array}$

Percentage (\%) of sensitivity of isolates to various antibiotics

E. coli $(n=68) \quad$ S. aureus $(n=36)$

Sensitive Intermediate Resistant.

$\begin{array}{ccc}17(47.2) & 7(19.4) & 12(33.3) \\ 8(21.1) & 4(11.1) & 24(66.7) \\ 0(0) & 0(0) & 36(100) \\ 6(15.8) & 2(5.6) & 28(77.8) \\ 0(0) & 0(0) & 36(100) \\ 2(5.3) & 1(2.8) & 33(91.7) \\ 0(0) & 1(2.6) & 35(97.2) \\ 1(2.6) & 7(19.4) & 28(77.8) \\ 9(25) & 4(11.1) & 23(63.9) \\ 33(91.7) & 2(5.5) & 1(2.8) \\ 32(88.9) & 4(11.1) & 0(0) \\ 3(8.3) & 3(8.3) & 30(83.3) \\ 2(5.6) & 1(2.6) & 33(91.7) \\ 2(5.6) & 2(5.5) & 33(91.7)\end{array}$

Key:

Sensitive: a zone within $3 \mathrm{~mm}$ radius of that of the positive control.

Resistant: a zone of not more than $2 \mathrm{~mm}$ radius.

Intermediate: a zone falling between the above limits.

\section{Discussion}

The high number of bacterial growth observed in this study suggested an infectious process by organisms such as E. coli and S. aureus which causes a variety of suppurative (pus forming) infections and toxinoses in humans

This study revealed that 148 (74\%) of the 200 female students had both symptomatic and asymptomatic lower genital tract infection. This finding suggests increased risk of infection of the female students. Earlier studies by Olartan (2006) reported a prevalence of $10 \%$ asymptomatic genital tract infection in female students' population of Nigerian University. Anh et al., (2003) reported a prevalence of $20.12 \%$ asymptomatic Bacterial vaginosis infection among women attending maternal and child health and family planning clinic in Hannoi, Vietnam. Some researchers have previously reported that BV is more common among younger women (Bukusi et al., 2006), while others like Morris et al., (2001) and Jones et al., (2007) found that risk of $\mathrm{BV}$ increases with age which is a proxy for cumulative sexual activity, especially, women between 15-20 years of age. BV has been associated with a variety of sexual behavior-related characteristics including young age at coitarche, life time number of sex partners, a recent history of multiple sex partners and a recent history of a new sex partner (Hay and Ugwumadu 2009). This result is very similar to the one in this study where the age bracket of the females was between 17-29 years with a mean age of 23 years. Bornstein et al., (2001) and Shobeiri et al., (2006) found out that out of 117 women with documented clinical information, the common symptom found was vaginal discharge in $39.3 \%$ followed by itching $31.6 \%$. They further said this 
number was consistent with vaginal infections. The high prevalence observed could be possibly due to increase in sexual activity among the university age group (Olartan, 2006). In this work, it was found out that out of 200 female students, $144(72 \%)$ of them admitted having one sexual partner, while $22(11.0 \%)$ had 2 sexual partners each. Further support for sexual transmission of BV comes from a treatment trial by Bradshaw et al., (2006), that found BV recurrence was 3 times more common among women who remained with their regular sexual partner after treatment and was significantly less likely among women who changed sexual partners. It may also be attributed to the difference in socio-economic and hygienic level of people. Some studies have found a relationship between BV and high-risk behaviours associated with sexually transmitted infections (STIs) such as early sexual debut and multiple sex partners (Larsson, et al., 2005). According to Olartan (2006), asymptomatic $\mathrm{BV}$ occurred relatively more frequently in females as compared with males and it is a major criterion of urinary tract infection (UTI). Fleury (1981) reported that BV is the leading cause of vaginal symptoms such as vaginal discharge and pruritus in developed communities of Rwanda. The most frequent symptom reported, according to Geisler et al., (2003) among 296 women for routine first time visit in a clinic but diagnosed to have BV was vaginal discharge (46\%), with vaginal odour (28\%), and genital itching $(15 \%)$ This agrees with our findings in this work where $71(35.5 \%)$ out of 200 had various degrees of vaginal odour, itching and vaginal discharge.

According to Roberta et al., (2002), most women reported douching for symptoms or hygiene, both of which elevated BV and vaginal colonization by organisms. In this work, the female students admitted using either soap or antiseptics and hence, increased the level of BV symptoms, but deferred by the fact that vaginal discharge was the least in our findings. In the work of Roberta et al., (2002), he reported that women with vaginal symptoms were found to douche and this led to elevated bacterial vaginosis. According to Ness et al., (2002) and Holzman et al., (2001), women douche following the development of BV in response to abnormal symptoms; however, in cross-sectional analyses, douching for reasons not associated with symptoms remains associated with BV. The research conducted in this work show a significant effect of douching method on the various vaginal symptoms for bacterial vaginosis. This is similar with the results of Roberta et al., (2003) in which they evaluated the relationship between risk factors such as vaginal symptoms and racial factors among black women and white women as it relates to douching, and was found out that BV increased among black women.

In the works of Muvunyi et al., (2009), there was low sensitivity and low positive predictive value (PPV) while specificity was high using vaginal discharge as a gold standard. This was similar to the findings of this research with low sensitivity (28.1), low PPV of $22.0 \%$ (P> $0.05 \%)$ and high specificity of $65 \%$ for BV, also using vaginal discharge as a gold standard.

According to Smith et al., (1999) and Veeh et al., (2003), Staphylococcus aureus is one of the most common causes of infection, incidence of which has been steadily increasing. The vaginal mucosa of females is colonized by this organism (Schlievert et al., 2007). In the work of Gilbert et al., (2002), vaginal microorganisms associated with vaginal infection and hence BV were found to be mainly group B Streptococci, S. aureus and E. coli. McDonald et al., (1994) found E. coli to be important pathogens associated with midtrimester pregnancy losses, alongside the classic bacterial vaginosis organisms. Staphylococcus aureus is one of the most persistent pathogen of humans and has remained one of the most common causes of infection, incidence of which has been steadily increasing (Smith et al., 1999; Butt, 2001). Olusanya and Olutiola (1984) isolated S. aureus (25\%) from majority of healthy female students, closely followed by E. coli (21\%). Omer and Ahmed (1992) found S. aureus as the commonest case in asymptomatic lower genital tract infection and hence, bacterial vaginosis followed by E. coli. This result is similar with the microorganisms isolated in this work but in contrast with the $65.4 \%$ and $34.5 \%$ for E.coli and S. aureus respectively in this study. This contradicts with the work of Peipert et al., (2003) were other organisms were isolated such as Gardnerella vaginalis, Mycoplasma sp. and anaerobes, but agrees with the results of Olartan (2006) who also found E. coli to be more prevalent. The author also isolated S. aureus among other micro organisms. Anh et al., (2003) reported the presence of Candida spp. in asymptomatic lower genital tract infection, and hence, bacterial vaginosis. Mahdi and Maysoon (2001) reported the isolation of S. aureus $(10 \%)$ and E. coli (8\%) as part of vaginal microorganisms associated with BV. This work varied slightly with previous work who reported a high prevalence of S. aureus (Akerele, 2001) and Candida Spp. in the vaginal flora (Mumtaz, et al., 2008). The absence of Neisseria gonorrhoeae in this work is consistent with the findings of Anh et al., (1996) which could be due to antibiotic usage.

The vaginal flora of adult females contains lactobacilli responsible for maintaining the vaginal $\mathrm{pH}$ and preventing the overgrowth of potential pathogens. This helps in reducing the frequency of infections at such age group. Antibiotics like broad-spectrum penicillins or tetracyclines can kill or suppress helpful bacteria in the genital tract, allowing resistant organisms to grow unchecked (Lowy, 1998).

Tariq et al., (2006) reported that the presence of members of faecal flora in the vagina was attributed to unhygienic bowel practice in the past. Martin et al., (1999) and Sewankambo, et al., (1997) reported that various studies across the world show that women with bacterial vaginosis (BV) are more likely to be co-infected with herpes simplex virus type-2 (HSV-2), Trichomonas vaginalis, Neisseria gonorrhoeae and HIV. This deviated 
from the result obtained in this study because HIV screening was not part of the main study. High co-infection rates with other STIs raise the possibility that BV may either increase susceptibility to STI or share a common pathway with other STIs as reported by Moodley et al., (2002). This is different from the results of this work. Candida spp. was the most common cause of vulvovaginitis among female children (Mandi and Maysoon, 2001). It has been isolated from vaginal swabs in $0 \%$ to $22 \%$ of asymptomatic adults (Linder and Planteina, 1978, Mahdi and Maysoon, 2001), 35\% of adolescents aged 11 to 15 years and $26 \%$ of apparently healthy children (Mahdi and Maysoon, 2001). Another study also indicates that there was no difference between the sexually active and non-active adolescents (Shafer et al., 1985). In Basrah, Candida spp. has been recovered at a rate of $13.9 \%$ and $31.1 \%$ in non-pregnant and pregnant women respectively (Mahdi and $\mathrm{Al}$ - Hamdani, 1998).

Various douching methods were seen to be practiced by the students, highest among which were those who douched with soap, $97(48.5 \%)$ with $74(76.3 \%)$ organisms isolated. $28(14 \%)$ students douched with antiseptics with $24(85.7 \%)$ organisms isolated. $75(37.5 \%)$ douched with water with $50(66.7 \%)$ organisms isolated. This is similar with the findings of Holzman et al., (2001) who found that vaginal douching within 2 months and above was associated with an increased prevalence of bacterial vaginosis. Fonck et al., (2001) found that, in female sex workers in Nairobi, Kenya, douching in general and douching with soap and water were both significantly associated with BV, with a significant trend for increased frequency of douching and higher prevalence of BV.

The most effective chemotherapeutic agents observed against E. coli in this study were ciprofloxacin $52(76.5 \%)$ and tarivid $52(77.9 \%)$. Least activity was noted against tetracycline, for E. coli, with a sensitivity of $2(3.0 \%)$ and a resistance of 66(97.1\%) followed by penicillins and ampicillins. This is the same thing for S. aureus with resistance of 35(97.2\%) for tetracycline and 33(91.7\%) for penicillins. This contradicts with the work of Akhtar et al., (1997) and Mumtaz et al., (2002) who reported a 98.64\% effectiveness for imipenem and $93.6 \%$ for vancomycin against $\mathrm{S}$. aureus infection but agrees with the less effectiveness of penicillins, tetracycline and sulphonamides. The most effective chemotherapeutic agent against $\mathrm{S}$ aureus in this work were ciprofloxacin 33 (91.7\%) followed by tarivid $32(88.9 \%)$. The organism was completely resistant to cotrimoxazole and nalidixic acid $0(0 \%)$ in each. The level of antibiotic resistance observed in this study especially penicillins and ampicillins could be attributed to the possession of the enzyme $\beta$-lactamase by these organisms leading to resistance against the main stay antibiotics for managing S. aureus and E. coli infections (Akhtar et al., 1997 and Mumtaz et al., 2008).

\section{Conclusion}

The high prevalence of asymptomatic bacterial vaginosis infection recorded in this study demands that patients with gynecological symptoms are investigated thoroughly and a routine screening of HVS of female students for asymptomatic lower genital tract infection be instituted as part of health care for females.

From the study, it was also found that almost all the students practiced one form of douching or the other, either with antiseptics or soap which was found to contribute to the proliferation of one form of organism or the other in the genital tract leading to BV.

\section{Recommendations}

While improved level of hygiene is likely to assist in reducing asymptomatic lower genital tract infection, and hence bacterial vaginosis, the general public should be educated on the danger in taking unprescribed drugs and therefore stop indiscriminate use of antibiotics. Over congestion of facilities especially the conveniences should be avoided in order to reduce the spread of this bacterial and yeast infections among the female students. The use of condoms or total abstinence should be encouraged among the female undergraduates. This will help in reducing sexually transmitted infections including BV.

The females should always clean from forward to backwards after using the toilet so as not to transfer the micro organism from the bowel to the vagina. This will help reduce the high rate of asymptomatic bacterial vaginosis infection among university female students.

The female students should be made to be aware of the dangers of douching, especially with antiseptics as they have, over time, believed it's a normal and a healthy form of maintaining hygiene within the genital region.

Reporting of any form of symptoms of lower genital tract infections such as burning vaginal sensations, yellow, creamy or whitish vaginal discharge with foul or offensive, fishy odour and itching, should be promptly reported at the school's medical centre for laboratory investigation and proper treatment. This is to avoid complications that may arise from untreated cases.

Multiple sexual partners should be discouraged and the use of protective barriers such as condoms or the female diaphragms preached. 


\section{References}

[1]. Abularach, S. and Anderson, J. (2005). Gynaecologic problems: A guide to the clinical management of women with HIV. Rockville, MD: Health Resourses and Services Administration, HIV/AIDS Bureau.

[2]. Adad, S.J., de Lima, R.V., Sawan, Z.T. and Silva, M.L. (2001). Frequency of Trichomonas vaginalis, Candida sp and Gardnerella vaginalis in cervical-vaginal smears in four different decades. Sao Paulo Med J. 1;119(6):200-5.

[3]. Akerele, J.P., Abhulimen, and Okonofua, F. (2002). Prevalence of asymptomatic genital infection among pregnant women in Benin City, Nigeria. J. Obstetr Gynaecol. 21:141-144.

[4]. Akhtar, N., Khan, H.H., and Khan I.A., (1997). Antibiotic susceptibility pattern of 196

[5]. strains of S. aureus isolated from patients at Bahawalpur. J. Ayub Med. Coll. Abottabad. 9(2):29-33

[6]. Amsel, R., Totten P.A., and Spiegel C.A.(1983). Nonspecific vaginitis: diagnostic criteria and microbial and epidemiologic associations. Am J. Med, 74:14-22.

[7]. Anh, P.T., Mai, T.P., and Phuong, H.T. (1996). Prevalence of lower genital tract infections among Vietnamese women attending a maternal and child Health Centre in Hanoi, Vietnam. Southeast Asian J. Trop. Med. Public Health, 27:193 - 195.

[8]. Anukam, K.C., Osazuwa, E.O., Ahonkhai, I. and Reid, G. (2006). Lactobacillus vaginal microbiota of women attending a reproductive health care service in Benin City, Nigeria. Sex. Trans. Dis. 33(1):59-62.

[9]. Aral, S.O., Mosher, W.D. and Cates, W. (1992). Vaginal douching among women of reproductive age in the United States: Am. J Public Health. 82:210-4.

[10]. Barbone, F., Austine, H., and Louv, W.C. (1990). A follow-up study of methods of contraception, sexual activity and rates of trichomoniasis, candidiasis and bacterial vaginosis. Am. J. Obstet Gynecol. 163:510-4.

[11]. Bauters,T.G., and Dhont, M.A. (2002). Prevalence of vulvovaginal candidiasis and susceptibility to fluconazole in women. American Journal of Obstetrics and Gynecology 187 (3):569 - 574.

[12]. Bornstein,J., Lakovsky, Y. and Lavi, I. (2001). The classic approach to diagnosis of vulvovaginitis: a critical analysis. Infec. Dist. Obstet Gynecol. 9:105-11.

[13]. Bramley, H.M., Dixon, R.A. and Jones, N.M. (1981). Haemophilus (Corynebacterium vaginalis, Gardnerella vaginalis) in a family planning clinical population. Br. J Verner Dis, 57:62-66.

[14]. Brotman, R.M., Ghanem, K.G., and Klebanoff, M.A. (2008). The effect of vaginal douching cessation on bacterial vaginosis: a pilot study. Am J. Obstet Gynaecol. 198(628):1-7.

[15]. Bukusi, E.A., Cohen, C.R., Meirr, A.S., Waiyaki, P.G. and Nguti, R. (2006). Bacterial vaginosis: risk factors among Kenyan women and their male partners. Sex Transm Dis 33:361-7.

[16]. Bump, R.C., Zuspan, F.P., Buesching, W.J. and Stephens,T.J. (1984). The prevalence, six-month persistence and predictive values of laboratory indicators of bacterial vaginosis in asymptomatic women. Am J Obstet Gynaecol; 150:917-24.

[17]. Burstein,G.R. and Zenilman, J.M. (1999). Nongonococcal urethritis-a new paradigm.Clin Infect Dis 1:S66-73.

[18]. But, T. (2001). The inexorable march of S. aureus. Pak. J. Pathol, 12: 1-3.

[19]. Carr, P.L., Felsenstein, D. and Friedman, R.H. (1998). Evaluation and management of vaginitis. J. Gen. Intern. Med. 13:335-46.

[20]. Centers for Disease Control and Prevention. (1998). Guidelines for treatment of sexually transmitted diseases. MMWR Morb. Mortal. Wkly. Rep. 47(RR-1):1-111.

[21]. Center for Disease Control and Prevention. (2002). Sexually transmitted diseases treatment guidelines. MMWR, 51 (RR -6): $1-78$.

[22]. Chacko, M.R., McGill, L., and Johnson, T.C. (1989). Vaginal douching in teenagers attending a family planning clinic. J. Adoles. Health Care, 10:217 - 219.

[23]. Chaisilwattana, P. and Monif, G.R. (1995). In vitro ability of the group B streptococci to inhibit gram-positive and gram-variable constituents of the bacterial flora of the female genital tract. Infect. Dis. Obstet Gynecol. 3:91-7.

[24]. Chattopadhyay, B. and Teli, J.ZC. (1984). Isolation of Gardnerella vaginalis from routine genitor-urinary tract specimens. J. Infect. 8:157-62.

[25]. Cheesbrough, M. (2000). District. Laboratory Practice in Tropical Countries. Part 2. Cambridge University Press, London. Pp343.

[26]. Chen, K.C, Forcyth, P.S. and Buchanan, T.M. (1979). Amine content of vaginal fluid from untreated and treated patients with nonspecific vaginitis. Clin Invest. 63:828-35.

[27]. Cherpes, T.L., Melan, M.A., Kant, J.A. and Cosentino, L.A. (2005). Effects of hormonal contraception, bacterial vaginosis and vaginal group B streptococcus colonization. Clin Infect Dist. 40:1422-8.

[28]. Colli, E., Landoni, M. and Parazzini, F. (1997). Treatment of male partners and recurrence of bacterial vaginosis: a randomized trial. Genitourin Med. 73:267-70.

[29]. Cook, S. W., Hamonill, H. A. and Hull, R. A. (2001). Virulence factors of Esherichia coli isolated from female reproductive tract infections and neonatal sepsis. Infect. Dist. Obstet Gynecol, 9:203-207.

[30]. Cotch, M.F., Pastorek, J.G., Nugent, R.P. and Eschenbach, D.A. (1991). Demographic and behavioral predictors of Trichomonas vaginalis infection among pregnant women. Obstet. Gynecol. 78:1087-92.

[31]. Cotch, M.F., Hillier, S.L., Gibbs, R.S. and Eschenbach, D.A. (1998). Epidemiology and outcomes associated with moderate to heavy Candida colonization during pregnancy.V aginal Infections and Prematurity Study Group. Am. J. Obstet Gynecol. 178:37480 .

[32]. CU - Uvin, S. Hogan, J. W., and Wareen, D. (1999). Prevalence of lower genital tract infections among human immunodeficiency virus (HIV) - seropositive and high risk HIV - seronegative women. HIV Epidemiology Research Study Group. Clin Infect. Dis. 29:1145-1150.

[33]. CU - Uvin, S. Hogan, J. W., Caliendo, A.M., Harwell, J., Mayer,K.H. and Carpenter, C.C. (2001). HIV epidemiology Research Study: Association between bacterial vaginosis and expression of human immunodeficiency virus type 1 RNA in the female genital tract. Clin. Infec. Dist. 33:894-6.

[34]. Cu-Uvin, S., Ko, H, Jamieson, D.J., Hogan, J.W. Schuman, P., Anderson, J. and Klein, R.S. (2002). Epidemiology Research Study (HERS) Group. Prevalence, incidence and Persistence or recurrence of trichomoniasis among human immunodeficiency virus (HIV) - positive women and among HIV- negative women at high risk for HIV infection Clin. Infect. Dis., $34: 406-411$.

[35]. Dawson, S.G., Ison, C.A. and Easmon, C.S. (1982). Male carriage of Gardnerella vaginalis. Br. J. Vener Dist. 58:243-5.

[36]. De Lima Soares, V., de Mesquita, A.M., Cavalcante, F.G., Silva, Z.P., and Hora, V. (2003). Sexually transmitted infection in a female population in rural north-east Brazil: prevalence, morbidity and risk factors. Trop. Med. Int. Health. 8:595-603.

[37]. Draper, D., Donohoe, W., Mortimer, L and Heine, R.P. (1998). Cysterine proteases of Trichomonas vaginalis degrade secretory lenkocyte protease inhibitor. J-Infect. Dis; 178:815 - 819.

[38]. Duerr, A., Heilig, C.M., and Meikle, S.F.(2003). Incident and vulvovaginal candidiasis among human immunodeficiency virus infected women: risk factors and severity. Obstet Gynecol 101:548 - 556. 
[39]. Duff, P., Lee, M.L. and Hillier, S.L. (1991). Amoxicillin treatment of bacterial vaginosis during pregnancy. Obstet. Gynecol. 77:431-5.

[40]. Eckert, L.O., HAWES, S.E., Stevens, C.E. and Koutsky, L.A. (1998). Vulvovaginal candidiasis: clinical manifestation, risk factors, management algorithm. Obstet Gynaecol, 92:757-65.

[41]. Eschenbach, D.A. (1989). Emphasis on upper genital tract complications. Obstet Gynaec Clin North Am; 16:593-610.

[42]. Evans, A.L., Scally, A.J., Wellard, S.J. and Wilson, J.D. (2007). Prevalence of bacterial vaginosis in lesbians and heterosexual women in community setting. Sex Transm Infect. 83:470-5.

[43]. Ferris,D.G., Nyirjesy, P., Sobel, J.D. and Soper, D. (2002). Over-the-counter antifungal drug misuse associated with patientdiagnosed vulvovaginal candidiasis. Obstet Gynaecol. 99:419-25.

[44]. Fiscella, K. (1996). Racial disparities in preterm births. The role of urogenital infections. Public Health Reports, 111, 104-113.

[45]. Fleury, F.J. (1981). Adult vaginitis. Clin Obstet Gynaecol. 24(2): 407-38.

[46]. Forrest, K.A., Washington, A.E., and Daling, J. R. (1989). Vaginal douching as a possible risk factor for pelvic inflammatory disease. J. Natl. Med. Assoc; 81:159-165.

[47]. Forna, F. and Gulmezoglu, A.M. (2004). Interventions for treating trichomoniasis in women. Cochrane Database Syst Rev. (1):CD000218.

[48]. French J.I., McGregor, J.A., Draper D., Parker R., and McFee J. (1999). Gestational bleeding, bacterial vaginosis, and common reproductive tract infections: risk for preterm birth and benefit of treatment. 93(5 pt 1):715-24.

[49]. Gardner, H.L. and Dukes C.D. (1955). Haemophilus vaginalis: a newly defined specific infection. Am J Obstet Gynaecol. 69:962 976.

[50]. Geiger, A.M. and Foxman, B. (1996). Risk factors for vulvovaginal candidiasis: a case-control study among university students. Epidemiology. 7:182-7.

[51]. Geisler, W.M., Yu, S. and Venglarik M. (2004). Vaginal leucocyte counts in women with bacterial vaginosis: relation to vaginal and cervical infections. 80: 401-405.

[52]. Gerards,L.J., Cats, B.P. and Korstanje, J.A. (1985). Early neonatal group B streptococcal disease: degree of colonization as an important determinant. J. Infec. Dis. 11:119-24.

[53]. Girotis, A.W. (1998) Lipid hydroperoxide generation, turnover, and effector action in biological systems J. Lipid Res; 39:15291542 .

[54]. Glover, D.D. and Larsen, B. (1998). Longntudinal investigation of Candida vaginitis in pregnancy: role of superimposed anti-biotic use. Obstet. Gynaecol. 91:115-118.

[55]. Goldenberg, R., Klebanoff, M., Nugent, R., Krohn, M., Hillier, S.and Andrews W. (1996). Bacterial colonization of the vagina during pregnancy in four ethnic groups. Am J. Obstet Gynaecol; 174:1618-21.

[56]. Gray, R.H., Kigozi, G., Serwadda, D. and Nalugoda, F. (2009). The effect of male circumcision on female partners' genital tract symptoms and vaginal infections. Am J. Obstet Gynaecol. 200(42):e1-7.

[57]. Greenblatt, R. M., Bacchetti, P. and Barkan, S. (1999). Lower genital tract infection among HIV - infected and high risk uninfected women: Findings of the women's interagency HIV study (WHIHS). Sex. Transm. Dis.; 26:143-151.

[58]. Gujjar, P., Finucane, M. and Larsen, B. (1997). The effect of estradiol on Candida albicans

[59]. Hammerschlag, M.R., Alpert, I. and Rosner, P. (1978) Microbiology of the vagina in children: Normal and Potentially Pathogenic organisms. Pediatr, 62:57-62.

[60]. Hammerschlag, M.R., Alpert, S., and Onderdonk, A.B.(1978). Anaerobic microflora of the vagina in children. Am. J. Obstet Gynaecol, 131:853-860.

[61]. Hammil, H. (1989). Normal vaginal flora in relation to vaginitis. Obstet Gynaecol Infect, 16:329 - 336.

[62]. Handa, V.L., Bachus,K.E., Johnston, W.W. and Hammond, C.B. (1994). Vaginal administration of low dose conjugated estrogens. Obstet Gynaecol. 84:215-8.

[63]. Hanson, J. M., McGregor, J.A., Hilliier, S.L., Eschenbach, D.A. and Kreutner A.K., (2000). Metronidazole for bacterial vaginosis. A comparism of vaginal gel vs. oral therapy. J. Reprod. Med; 45:889-96.

[64]. Hawes, S.E., Hillier, S.L., Benedetti, J., Stevens, C.E. and Koutsky, L.A.(19960. Hydrogen peroxide-producing lactobacilli and acquisition of vaginal infections. 174:1058-63.

[65]. Hay,P.E. (1998). Recurrent bacterial vaginosis. Dermatol. Clin. 16:769-73, xii-xiii.

[66]. Hay, P. and Ugwumadu, A. (2009). Detecting and treating common sexually transmitted diseases.Best Pract Res Clini Obstet Gynaecol. 23:647-60.

[67]. Hill, G.B., Eschenbach, D.A. (1985). Bacteriology of the vagina. Scand. J. Urol Nephrol Supply; 86:23-39.

[68]. Hill, L.H., Ruparelia, H. and Embil, J.A. (1983). Non specific vaginitis and other genital infections in three clinic populations. Sex. Trans. Dis. 10:114-8

[69]. Hillier, S.L., Holmes, K.K., Sparling, P.F., Mardh, P.A., Lemon, S.M., Piot, P. and Wasserheit, J. N. (1999). Sexually Transmitted Diseases. $3^{\text {rd }}$. New york, McGraw-Hill, pp. 563-586.

[70]. Hillier, S.L., Nugent, R. P., Eschenbach, D.A., Krohn, M.A., Gibbs, R.S.and Martin, D.H., (1995). Association between bacterial vaginosis and preterm delivery of a low birth-weight infant. The vaginal Infections and prematurity Study Group. New England Journal of Medicine, 333(26), 1737-1742.

[71]. HIV/AIDS Bureau - Women's HIV/AIDS Care Guide, (2005). Bacterial vaginosis, vulvovaginal candidiasis,Trichomonas vaginalis. http://hab.hrsa.gor/publicaitons/women care 05/WG05chap6.htm. Accessed 18/9/2009.

[72]. Hoesprich, P.D., Jordan, M.C. and Ronald, A.R. (1994). Infectious diseases: A treatise of infectious processes. $5^{\text {th }}$ edition.

[73]. Holmes, K.K., Chen, K.C. and Lipinski, P.M. (1985). Vaginal redox potential in bacterial vaginosis (nonspecific vaginitis). J. Infect. Dist. 152:379-82.

[74]. Holts, E. Mardh and P.A (1984). Recovery of anaerobic curved rods and Gardnerella vaginalis from the urethra of men, including male heterosexual consorts of female carriers. Sand J Urol Nephrol Suppl, 86:173-7.

[75]. Holzman, C., Leventhal, J. and Qiu, H. (2001). Factors Linked to bacterial vaginosis in nonpregnant women. Am J. public Health; 91:1664-1670

[76]. Horowitx, B.J., and Mardh, P.A. (1991). Vaginitis and vaginosis. New York, Wiley Liss.

[77]. Hutchinson, K.B., Kip, K.E. and Ness,R.B. (2007). Condom use and its association with bacterial vaginosis and bacterial vaginosis-associated vaginal microflora. Epidemiology. 18:702-8.

[78]. Ison, C.A., Easmon, C.S. (1985). Carriage of Gardnerella vaginalis and anaerobes in semen. Genitourin Med. 61:120-2.

[79]. Jacobsson, B., Pernevi, P., Chidekel L. and Jorgen P.C. (2002). Bacterial vaginosis in early pregnancy may predispose for preterm birth and postpartum endometritis. Acta Obstet Gynaec Scand. 81: 1006-10. 
[80]. Jamieson, D. J., Duerr, A. and Klein, R.S. (2001). Longitudinal analysis of bacterial vaginosis findings from the HIV epidemiology research study. Obstet Gynecol; 98:656 - 663 .

[81]. Jeanne, S.M., Kim, M.O., Lorraine, V. and Klerman, D. (1999). Douching: a problem for adolescent girls and young women. Arch. Pediatr Adol Med. 153:834-837.

[82]. Jones, F.R., Miller, G., Gadea, N. Meza, R., and Leon, S. (2007). Prevalence of bacterial vaginosis among young women in low income populations of coastal Peru. Int J STD AIDS, 18:188-92.

[83]. Juliano, C., Piu, L., Gavini, E. and Zanetti, S. (1992). In vitro antibacterial activity of antiseptics against vaginal lactobacilli. Eur. J. Clin. Microbiol. Infect. Dis. 11:1166-9.

[84]. Kent, H.L. (1991). Epidemiology of vaginitis. Am. J. Obstetrics Gynaecology; 165 (4 pt 2)1168-76.

[85]. Khan, I. and Khan, U.A. (2004). A hospital based study of frequency of aerobic pathogens in vaginal infections. J Rawal Med Coll., 29(1):22-25.

[86]. Kharsany, A.B., Hoosen, A.A. and Moodley, J. (1997). Bacterial vaginosis and lower genital tract infections in women attending out-patient clinics at a tertiary institution serving a developing community. J. Obstet Gynecol. 17(2):171-5.

[87]. Kinghorn, G.R., Jones, B.R. and Chowdhury, F.H. (1984). Balanoposthitis associated with Gardnerella vaginalis infection in men. Br. J. Vener Dis. 58:127-9.

[88]. Klufio, C.A., Amoa, A.B. and Hombhanje, M. (1995). Prevalence of vaginal infections with bacterial vaginosis, Trichomonas vaginosis and Candida albicans among pregnant women at Port Moresby General Hospital Antenatal Clinic. PNG Med J. 38(3):163-71.

[89]. Koumans, E.H. and Kendrick, J.S., (2001). Preventing adverse sequelae of bacterial vaginosis: a public health program and res earch agenda. 28:292-7.

[90]. Laga, M. Manoka, A.T. and Kivuvu, M. (1993). Non ulcerative sexually transmitted diseases as risk factors for HIV-1 transmission in women: results from a cohort study. AIDS. 7:95-102.

[91]. Landers, D.V., Wiesenfeld, H.C., Heine, R.P., Krohn, M.R. and Hillier, S.L. (2004). Predictive

[92]. Larsen, B. (1994). Microbiology of the female genital tract. In: Obstetrics and Gynaecologic infections disease, New York. In: Postorck J, ed. Raven Press. PP. $11-25$.

[93]. Larsen, B. and Galask, R. (1982). Vaginal microbial flora: Composition and influence of host physiology. Ann Intern. Med, 96:926 -930 .

[94]. Larsen, B. and Moniff, G. (2001). Understanding the Bacterial flora of female Genital Tract Clinical Infectious Diseases, 32:69-77.

[95]. Larsson, P.G., Bergstrom, M., and Forsum,U. (2005). Bacterial vaginosis transmission, role in genital tract infection and pregnancy outcome. APMIS 113; 233-45.

[96]. Leitich, H. and Kiss H. (2007). Asymptomatic bacterial vaginosis and intermediate flora as risk factors for adverse pregnancy outcome. Best Pract Res Clin Obstet Gynaecol. 21:375-90.

[97]. Leopold, S. (1953). Herotofore undescribed organism isolated from the genitourinary system. US Armed Forces Med J. 4:263-266.

[98]. Lindau, S.T., Mendoza, K. and Surawsk, H. (2007). Vaginal Swab Measurement of Candidiasis in Wave I of the National Social Life, Health \& Aging Project (NSHAP) NORC and the University of Chicago. http://biomarkers.uchicago.edu/pdfs/TR- vaginal \% 20 candidiasis. Pdf.

[99]. Lindau, S.T. and Hoffmann, J.N. (2008). 'Vaginal Self-Swab Specimen Collection in a Home-based Survey of Older Women: Methods and Applications.'Journals of Gerontology: Social Sciences Special Issue on the National Social Life, Health and Aging Project.

[100]. Linder, G.E., Plantema, F.H. Hoog, K. and Korstanje, J.A. (1978). Quantitative studies of the vaginal flora of health women and obstetrics and gynaecological patients. J. Med. Microbiol; 11:233-241.

[101]. Lossick, J.G. and Kent, H.L. (1991). Trichomoniasis: trends in diagnosis and management. Am J. Obstet. Gynecol. 165:1217-22.

[102]. Lurie, S., Woliovitcch, I., Rotmensch, S. Sadan, O. and Glezerman, M. (2001). Value of vaginal culture in management of acute vaginitis. Arch Gynaecol Obstet, 265:187-9.

[103]. Mabey, D., Peeling,R.W. and Perkins, M.D. (2001). Rapid and simple point of care diagnostics for STIs. Sex Transm Infection. 77:397-8.

[104]. Marrazzo, J.M., Koutsky, L.A. and Eschenbach, D.A. (2002). Characterization of vaginal flora and bacterial vaginosis in women who have sex with women. J. Infect Dis. 185:1307-13.

[105]. Mari, E.E. and Martin, S.L., (2000). Diagnosis of vaginitis. Am Fam Physician. 158:935-9.

[106]. Martin, H.L., Richardson, B.A., and Nyange, P.M. (1999). Vaginal lactobacilli, microbial flora, and risk of human immunodeficiency virus type 1 and sexually transmitted disease acquisition. J. Infect. Dis., 180:1863 - 1868.

[107]. Martino, J.L. and Vermund, S.H. (2002). Vaginal Douching: Evidence for Risk or Benefits to Women's Health. Epidemiologic Reviews, 24: $109-124$.

[108]. McCaffrey, M., Varney, P. and Taylor-Robinson, D. (1999). Bacterial vaginosis: evidence for lack of sexual transmission. Int J. STD AIDS. 10:305-8.

[109]. McCormick, W.M., Hays, C.H. and Rosner, B. (1977). Vaginal colonization with Corynebacterium vaginale (Haemophilus vaginalis). J. Infect. Dist. 136:740-5.

[110]. McDonald, H.M., O'Loughlin, J.A., and Bof. A., (1997). Impact of metronidazole therapy on preterm birth in women with bacterial vaginosis flora (Gardnerella vaginitis): a randomized, placebo controlled trial. Br. J. obstet. Gynaecol. 104 :1391-7.

[111]. Miller, H.G., Cain, V.S. and Rogers, S.M. (1999). Correlates of sexually transmitted bacterial infections among U.S. women in 1995. Fam. Plann. Perspect. 31:4-9,23.

[112]. Moi, H., Errkola, R., Jerve, F., Nelleman, G. and Bymose, B. (1989). Should men consorts of women with bacterial vaginosis be treated? Genitourin Med. 65:263-8.

[113]. Monif, G. R. and Larson, H. J. (1998). Female genital tract bacterial coisolates with Candida albicans in patients without clinical vaginitis. Infect. Dis. Obstet. Gynecol. 6:52-56.

[114]. Monif, G.R. Welkos, S.L. and Baer, H. (1982). Impact of diverging anaerobic technology on cul-de-sac isolates from patients with endometritis / salpingitis / peritonitis. Am J. Obstet. Gynecol, 124:896 - 900.

[115]. Monif, G.R.(1985). Pathogenesis and classification of vulvovaginal candidiasis. Am. J. Obstet. Gynaecol. 152:935-439.

[116]. Monif, G.R., (1999). The great douching debate: to douche, or not to douche. Obstet. Gynaecol, 94:630 - 631.

[117]. Monif, G.R., Thompson, J.L.and Stephens, H.D. (1980). Quantitative and qualitative effects of povidone - iodine liquid and gel on the aerobic and anaerobic flora of female genital tract. Am. J. Obstet. Gynaecol, 137:432 - 428.

[118]. Morris, M. Nicoll, A., Simms, I., and Wilson, J. (2001). Bacterial vaginosis: A public health review. BJOG, 108:439-50

[119]. Mumtaz, S., Mumtaz, A. Irum A., Naeem, A., Masood, U. H. and Hamid, A. (2008). Aerobic vaginal pathogens and their sensitivity pattern. J. Ayub. Med. Coll Abbottabad, 20(1): 113 - 117. 
[120]. Mumtaz, S., Akhtar, N., and Hayat, A. (2002). Antibiogram of aerobic pyogenic isolates from wounds and abscesses of patients at Rawalpindi. Pakistan J. Med. Res. 41(1):16-18.

[121]. Mylonas, I. and Friese, K. (2007). Genital discharge in women. MMW Fortschr Med; 149 (35 - 36): 42 - 46.

[122]. National AIDS Control Organisation (NACO), India.(2004). Flow charts on the management of sexually transmitted infections. Http://www.nacoonline.org/publications/flowcharts.pdf.

[123]. Neal, R.C. (2004). Vaginitis. nchamberlain@atsu.edu. Accessed 6/15/2010

[124]. Ness, R.B., Soper, D.R., Holley, R.L. and Peipeit, J. (2001). Douching and endometritis:Results from the PID evaluation and clinical health (PEACH) study. Sex. Transm. Dis. 28:240-5.

[125]. Ness, R. Hillier, S. and Richter, H. (2002). Douching in relation to bacterial vaginosis, lactobacilli, and facultative bacteria in the vagina. Obstet Gynaec; 100: 765-772.

[126]. Newton, E.R., Piper, J.M. and Shain, R.N. (2001). Predictors of the vaginal microflora. Am J. Obstet Gynaecol, 184:845 - 855.

[127]. Nyirjesy, P. (2008). Vulvovaginal candidiasis and bacterial vaginosis. Infect Dis Clin North Am, 22:637-52.

[128]. Oakeshott P., Hay, P. and Kerry,S. (2002). Association between bacterial vaginosis or Chlamydial infection and miscarriage be fore 16 weeks' gestation: prospective community based cohort study.BMJ. 325:1334.

[129]. Ochei, J. and Kolhatkar, A.(2008).Medical laboratory Science. Theory and Practice.

[130]. Octavio, F.L. and Lantero, Dra M.I. (2004) Prevalence of Candida albicans and Trichomonas vaginalis in pregnant women in Havana City by an immunologic Latex Agglutination Test. Med Gen Med, 6(4):50.

[131]. Olusanya, B. and Olutiola, P.O. (1984). Studies of bacteriuria in patients and students in Ile-Ife, Nigeria. West Africa Journal of Medicine, 3(3): 177 - 183.

[132]. Omer, E.E. and Ahmed, E.I. (1992). Urinary tract infection in school children Medicine Digest, 18 (6): 3 - 7.

[133]. Onderdonk, A.B., Delaney, M.L. and Hinkso, P.L. (1992). Quantitative and qualitative effects of douche preparations on vaginal microflora. Obstet Gynaecol, 80:333 - 338 .

[134]. Pandit, L. and Ouslander, J.G. (1997). Postmenopausal vaginal atrophy and atrophic vaginitis. Am J Med Sci. 314:228-31.

[135]. Pavlova, S.I. and Tao, L. (2000). In vitro inhibition of commercial douche products against vaginal microflora. Infect. Dis Obstet, 8:99- 104.

[136]. Peipert, J.F., Motagno, A.B., and Cooper,A.S. (2003). Bacterial vaginosis as a risk factor for upper genital tract infection. Am. J. Obstet Gynaec.177:1184-7.

[137]. Penney, G.C. (1997). Preventing infective sequelae of abortion. Hum Reprod 12:107-12.

[138]. Percival - Smith, R. (1983). Vaginal colonization of Esherichia coli and its relation to contraceptive methods. Contraception, 27:497-504.

[139]. Petrin, D. Delgaty, K. and Bhatt, R. (1998). Clinical and microbiological aspects of Trichomonas vaginalis. Clinical Microbiol Rev. 11:300-17.

[140]. Piot, P., Van Dyck, E., and Holmes, K.K. (1984). Biotypes of Gardnerella vaginalis. J. Clin Microbiol. 20:677-9.

[141]. Potter, J. (1999). Should sexual partners of women with bacterial vaginosis receive treatment? Br. J. Gen Pract. 49:913-918.

[142]. Prescott, L.M., Harley, J.P. and Klein, D.A. (2005). Microbiology. McGrew - Hill, New York. $5^{\text {th }}$ ed. Pp. 688.

[143]. Ramon, A.M., Porta, A. and Fonzi, W.A. (1999). Effect of environmental pH on morphological development of Candida albicans is mediated via the Pac C related transcription factor encoded by PRR2. J. Bacteriol, 81:7524 - 7530 .

[144]. Riordan, T., Macaulay, M.E., James, J.M., and Leventhal, P.A. (1990). A prospective study of genital infections in a familyplanning clinic. Microbiological findings and their association with vaginal symptoms. 104(1):47-53.

[145]. Roberta, B.N., Sharon, L.H., Holly, E.R., and David, E.S. (2002). Douching in relation to bacterial vaginosis, lactobacilli, and Facultative bacteria in the vagina. 100:765-72.

[146]. Rosenberg, M.J., Phillips, R.S., and Holmes, M.D. (1991). Vaginal douching Who and why? J. Reprod. Med., 36:753 - 758.

[147]. Rosenberg, M.J. and Philips, R.S. (1992). Does douching promote ascending infection? J. Reprod. Med., 37:930-8.

[148]. Roy, S., Sharma, M.1., Ayyagari, A. and Malhotta, S. (1994). A quantitative study of bacterial vaginosis. Indian J. Med. Res., 100:172-176.

[149]. Savage, D.C. (1969). Microbial interference between indigenous yeast and lactobacilli in the rodent stomach. J. Bacteriol, 98:1278 1283 .

[150]. Scaaf, V.M., Perez-Stable,E.J. and Borchardt, K. (1990). The limited value of signs and symptoms in the diagnosis of vaginal infections. Arch. Intern. Med.150:1929-33.

[151]. Shafer, M.A., Sweet, R.L., Shalwitz, J. and Schacter, J. (1985). Microbiology of lower genital tract in postmenarchal adolescent girls: differences by sexual activity, contraception, and presence of nonspecific vagitis. J. Pediatr. 107:974-81.

[152]. Shah, D. and Larsen, B. (1992). Identity of a Candida albicans toxin and its production in vaginal secretions. Medical Science Research. 20:353-5.

[153]. Schenbach, D.A. and Hillier, S.L. (1989). Advances in diagnostic testing for vaginitis and cervicitis. J. Reprod. Med; 34:555 - 564.

[154]. Schlievert, P.M., Case, L.C., Strandberg, K.L., Timothy L., Tripp, T.L., Linn, Y.C. and Paterson, M.L. (2007). Vaginal staphylococcus aureus superantigen profile - shift from 1980 and 1981 to 2003, 2004 and 2005. J. Clin Microbial, 45:2704 - 2707.

[155]. Schuchat, A. and Wenger, J.D. (1994). Epidemiology of group B streptococcal disease: risk factors, prevention strategies and vaccine development. Epidemiol. Rev. 16:374-402.

[156]. Schwebke, J.R. (2000). Vaginal infections. Women and health San Diego, C.A. Academic Press. In: Goldman, M.B., Hatch, M.C. eds. $352-360$.

[157]. Schwebke, J.R. (2003). Gynaecologic consequences of bacterial vaginosis. Clin North Am. 30:685-94.

[158]. Sewankambo, N., Gray, R.H. and Wawer, M.J. (1997).HIV-1 infection associated with abnormal vaginal flora morphorlogy and BV. 350:546-50.

[159]. Sexually Transmitted disease guidelines. (2002). Recommendations and reports. Vol.51/No.RR-6. (http://www.cdc.gov/std/treatment/TOC2002TG.htm).

[160]. Shafer, M.A., Sweet, R.L., Ohm-Smith, M.J.(1985). Microbiology of the lower genital tract in Postmenarehal adolescent girls. Differences by sexual activity, contraception and presence of non-specific vaginitis. J. Pediatr., 107:974-981.

[161]. Shah, D. and Larsen, B. (1992). Identity of a Candida albicans toxin and its production in vaginal secretions. Medical Science Research. 20:353-5.

[162]. Shubair, M. Synder, I.S. and Larsen, B. (1993). Gardnerella vaginalis haemolysin III. Effects of human leucocyte. Immune Infec Dis. 3:149-53.

[163]. Smith, T.L., Pearson, M.L., Wilcox, K.R., Cruz C., Lancaster, M.L., Robinson - Dunn, B. (1999). Emergence of vancomycin resistance in Staphylococcus aureus: epidemiology and clinical significance N Engl 3. Med. 340: 493 - 501.

[164]. Sobel, J. D. (1997). 'Vaginitis'. New England Journal of Medicine, 337 (26): 1896-1903. 
[165]. Sobel, J.D. (1999). Vulvovaginitis in healthy women. Compr. Ther. 25:335-46.

[166]. Sobel, J.D. (2005). "Genital Candidiasis." Medicine 33(10): 62-65.

[167]. Sobel, J.D. (2007). "Vulvovaginal candidiasis" Lancet, 369 (9577): 1961 - 1971.

[168]. Sobel, J.D. and Chaim, W. (1996). Vaginal Microbiology of women with a cute recurrent vulvovaginitis candidiasis. D. clin. Microbiol, 34:2497-2499.

[169]. Sobel, J.D. (2001). Recurrent vulvovaginal candidiasis (RVVC). Int J STD AIDS. 12(suppl 2):9.

[170]. Spear, G.T., St. John, E. and Zariffard M.R. (2007). Bacterial vaginosi and human immunodeficiency virus infection. 4:25.

[171]. Spiegel, C. A., Amsel, R., Eschenbach, D. Schoenknecht, F. and Holmes, K.K. (1980). Anaerobic bacteria in nonspecific vaginitis. N Engl J. Med; 303:601-7.

[172]. Spiegel, C.A., Amsel, R., Eschenbach, D., Schoenknecht, F. and Holmes, K.K. (1980). Anaerobic bacteria in nonspecific vaginitis. N. Engl J. Med; 303:601-7.

[173]. Steen, R. and Dallabetta, G.(2003). Sexually transmitted infection control with sex workers: regular screening and presumptive treatment augment efforts to reduce risk and vulnerability. Reprod Health Matters. 11:74-90.

[174]. Sturm, A.W. (1989). Chemotaxis inhibition by Gardnerella vaginalis and succinate-producing vaginal anaerobes: composition of vaginal discharge associated with G. vaginalis. Genitourin. Med. 65:109-12.

[175]. Swidsinski, A., Doerffel, Y. and Loening-Baucke, V.(2005). Gardnerella biofilm: males and females and is sexually transmitted. Gynaecol Obstet Invest. 106:1013-23.

[176]. Tariq, N., Jaffery, T., Ayub, R., Alam, A.Y., Javid, M.1. and Shafique, S. (2006). Frequency and antimicrobial susceptibility of aerobic vaginal isolates. J. Coll Physicians Surg Pak., 16 (3): 196 - 199.

[177]. Tchamouroff, S.E.and Panja, S.K. (2000). The association between receptive cunnilingus and bacterial vaginosis. Sex Transm Infect. 76:144-5.

[178]. Thomas, T., Choudhri, S., Kariuki, C. and Moses, S. (1996). Identifying cervical infection among pregnant women in Nairobi, Kenya:Limitations of risk assessment and symptom based approaches. Genitourin Med. 72:334-8.

[179]. Ugwumadu, A., Manyonda, I., Reid, F., and Hay, P. (2003). Effect of early oral clindamycin on late miscarriage and preterm delivery in asymptomatic women with abnormal vaginal flora and bacterial vaginosis: a randomized controlled trial . Lancet, 361:983-8

[180]. Uneke, C.J. and Moses, N.A. (2007). Non gonococcal and Nonchlamydial Microbial Isolates from High Vaginal Swabs of Nigerian Women Diagnosed with Pelvic Inflammatory Disease. Internet Journal of Infectious Diseases. Volume 6 Number 1.

[181]. Van De Wijgert, J.H., Mason, P.R., Gwanzura, L., Mbizvo, M.T. and Chirenje, Z.M., $\quad$ (2000). Intravaginal practices, vaginal flora disturbances, and acquisition of sexually transmitted diseases in Zimbabwean women. J Infect Dis;181(2):587-94.

[182]. Veeh, R.H., Shirtliff, M.E., Petik, J.R. and Flood, J.A. (2003). Detection of S. aureus biofilm on tempons and menses components. J Infect Dist. 188:519-30.

[183]. Verstraelen, H. and Verhelst, R. (2009). Bacterial vaginosis: an update on diagnosis and treatment. Expert Rev Anti Infect Ther. 7:1109-24

[184]. Vigneswaran, R. and McDonald, P.J. (1994). Changes in vaginal flora during pregnancy and association with preterm birth. J. Inf Dis. 170:724-28.

[185]. Warren, D., Klein, R.S. and Sobel, J. (2001). HIV Epidemiology Research Study (HERS) Group A multicenter study of bacterial vaginosis in women with or at risk for human immunodeficiency virus-infection. Infect. Dis. Obstet. Gynecol; 9:133-141.

[186]. White, S. and Larsen, B. (1997). Candida albicans morphogenesis is influenced by estrogen, cellular and molecular life sciences, 53:744-749.

[187]. Wolner - Hanssen, P., Eschenbach, D.A. and Paavo, N.J. (1990). Association between vaginal douching and acute pelvic inflammatory disease. JAMA, 263:1936 - 1941.

[188]. World Health Organisation. (2001). Guidelines for the management of sexually transmitted infections. WHO/AIDS; WHO/RHR/01.10.

[189]. Yotebieng, M., Turner, A.N. and Hoke, T.H. (2009). Effect of consistent condom use on 6-month prevalence of bacterial vaginosis varies by baseline BV status. Trop Med Int Health. 14:480-6.

[190]. Zenilman, J.M., Fresia, A. and McCormack, W.M. (1999). Bacterial vaginosis is not associated with circumcision status of the current male partner. Sex Transm Infect. 75:347-8

[191]. Zheng, H.Y., Alcorn, T.M. and Cohen, M.D. (1994). Effect of $\mathrm{H}_{2} \mathrm{O}_{2}$ producing Lactobacilli on Neisseria gonorrhoeae growth and catalase activity. J. Inf;ect Dis., 170:1209-1015.

[192]. Hill, L.H., Ruparelia, H. and Embil, J.A. (1983). Nonspecific vaginitis and other genital infections in three clinic populations. Sex Transm Dis 1983;10(3):114-8 